\title{
Sprawozdanie z Konferencji Naukowej „Panorama prawnych aspektów wielokulturowości społeczeństwa", Poznań, 20-21 kwietnia 2017 r.
}

W dniach 20-21 kwietnia 2017 r. w gmachu Wyższej Szkoły Bankowej (WSB) w Poznaniu odbyła się Konferencja Naukowa „Panorama prawnych aspektów wielokulturowości społeczeństwa", nad którą patronat honorowy objęli: dr Adam Bodnar Rzecznik Praw Obywatelskich oraz Jacek Jaśkowiak - Prezydent Miasta Poznania. Celem konferencji było zidentyfikowanie i zarysowanie, przez przedstawicieli różnych dyscyplin prawniczych, problemów i zagadnień, które z perspektywy nauk prawnych mają (lub mogą mieć) istotne znaczenie dla funkcjonowania społeczeństwa złożonego z osób reprezentujących różne kultury i różne narodowości, wyznających różne religie i posługujących się różnymi językami, będących obywatelami różnych państw.

Organizatorem konferencji był Instytut Prawa i Administracji Wyższej Szkoły Bankowej w Poznaniu, kierowany przez prof. dra hab. dra h.c. Andrzeja J. Szwarca. Profesor przewodniczył także Komitetowi Organizacyjnemu przedsięwzięcia. W skład Komitetu Naukowego, działającego pod przewodnictwem prof. dra hab. Józefa Stanisława Orczyka - rektora WSB w Poznaniu, weszli: prof. dr hab. Roman Budzinowski - dziekan Wydziału Prawa i Administracji Uniwersytetu im. Adama Mickiewicza w Poznaniu (UAM), prof. nadzw. dr hab. inż. Tadeusz Leczykiewicz prodziekan Wydziału Finansów i Bankowości WSB w Poznaniu, dr Roman Łosiński dziekan Wydziału Finansów i Bankowości WSB w Poznaniu, dr hab. Mieczysław Staniszewski, prof. WSB z Instytutu Prawa i Administracji WSB w Poznaniu, prof. dr hab. Piotr Stępniak - z Wydziału Studiów Edukacyjnych UAM, prof. dr hab. dr h.c. Andrzej J. Szwarc - dyrektor Instytutu Prawa i Administracji WSB w Poznaniu, prof. dr hab. Stanisław Wykrętowicz - z Instytutu Prawa i Administracji WSB w Poznaniu. Patronat medialny sprawowały: Telewizja Internetowa UAM.TV, Telewizja WTK, "Gazeta Wyborcza” oraz portal epoznan.pl. W konferencji uczestniczyło około siedemdziesięciu osób reprezentujących łącznie kilkanaście instytucji, w tym zwłaszcza szkoły wyższe oraz instytucje samorządowe. Na podkreślenie zasługuje osobisty udział Rzecznika Praw Obywatelskich - dra Adama Bodnara oraz czwartego zastępcy prezydenta Miasta Poznania - Jędrzeja Solarskiego. W programie konferencji znalazło się 26 referatów obejmujących szeroki wachlarz dostrzeganych z prawniczej perspektywy problemów związanych z wielokulturowością społeczeństwa.

Konferencję otworzył prof. dr hab. dr h.c. Andrzej J. Szwarc, witając zgromadzonych i przypominając cel, jaki przyświecał obradom. Następnie uczestników 
powitał rektor WSB w Poznaniu prof. dr hab. Józef Stanisław Orczyk, podkreślając w swym wystąpieniu doniosłość podejmowanej problematyki. Powitanie w imieniu Prezydenta Miasta Poznania wygłosił jego zastępca, Jędrzej Solarski, zaznajamiając gości z działaniami, jakie Miasto podejmuje w sferze przyjmowania i integracji imigrantów oraz w odniesieniu do osiadłych już osób reprezentujących odmienne niż większość kultury.

Pierwszą część konferencji, moderowaną przez prof. dra hab. Romana Wieruszewskiego (Instytut Nauk Prawnych Polskiej Akademii Nauk), otworzyło wystąpienie Rzecznika Praw Obywatelskich dra Adama Bodnara „Kontekst wielokulturowości w ochronie praw i wolności człowieka i obywatela". Kolejne referaty, wygłoszone przez prelegentów reprezentujących UAM, podejmowały temat wielokulturowości w szerokim, międzynarodowym kontekście. W tej części spotkania wystąpili: dr Natalia Buchowska - „Uniwersalizm a regionalizm praw człowieka w kontekście wielokulturowości społeczeństw”, dr hab. Tadeusz Gadkowski, prof. UAM - „Ewolucja zasady samostanowienia w kontekście wielokulturowości społeczeństw", dr Wojciech Szafrański - "Od koncepcji nacjonalistycznych do internacjonalistycznych w prawie ochrony dziedzictwa wielokulturowych dzieł sztuki/dóbr kultury".

Moderatorem części drugiej, poświęconej administracyjnoprawnym aspektom podejmowanej problematyki, był prof. dr hab. Roman Budzinowski. Reprezentująca WSB w Poznaniu mgr Agnieszka Narożniak przedstawiła referat nt. węzłowych problemów administracyjnoprawnej regulacji pobytu cudzoziemca, a dr hab. Wojciech Piątek z UAM omówił postępowanie o nadanie statusu uchodźcy.

Część trzecia pierwszego dnia konferencji poświęcona była aspektom wielokulturowości społeczeństwa oglądanym z perspektywy karnoprawnej, z uwzględnieniem problematyki proceduralnej. Funkcję moderatora pełnił prof. dr hab. dr h.c. Andrzej J. Szwarc. Najpierw dr hab. Justyn Piskorski (UAM) zarysował szeroki kontekst zagadnienia w wystąpieniu „Kryminologiczne i kryminalnopolityczne wyzwania wielokulturowości”. Następnie dr Michał Leciak (Uniwersytet Mikołaja Kopernika w Toruniu) przedstawił referat „Stan przestępczości cudzoziemców w Polsce w dobie kryzysu migracyjnego". Kolejne wystąpienie poświęcone zostało nabrzmiewającemu w ostatnich latach problemowi, jaki stanowi język debaty publicznej. Dr Anna Demenko (UAM) wygłosiła referat „Prawnokarna ocena wypowiedzi znieważających lub zniesławiających w społeczeństwach wielokulturowych". Następnie wystąpił dr hab. Janusz Bojarski (Uniwersytet Mikołaja Kopernika w Toruniu) z referatem "Reakcja na przestępstwa gospodarcze jako wyraz różnic kulturowych". Pierwszy dzień konferencji zamknęły rozważania dotyczące kwestii proceduralnych ujęte w referacie prof. dra hab. Pawła Wilińskiego oraz dr Martyny Kusak (UAM) „Wpływ wielokulturowości społeczeństwa na efektywność procesu karnego w Polsce".

Drugi dzień konferencji rozpoczął się od swego rodzaju nawiązania do tematyki podejmowanej na zakończenie dnia poprzedniego, dwa pierwsze wystąpienia dotyczyły bowiem aspektów funkcjonowania systemu penitencjarnego. Pierwszy referat przygotowali goście z Sam Houston State University w Stanach Zjednoczonych - prof. dr Jurg Gerber i Kate Angulski, M.A. Dotyczył on kwestii związanych z praktykami religijnymi w amerykańskich więzieniach („,Religion and Multicultural Prisons: A Brief Review of Issues in American Prisons and Jails”). Z kolei "Problemy 
wielokulturowości w polskim systemie penitencjarnym" zarysował prof. dr hab. Piotr Stępniak (UAM). Ponadto wygłoszony został referat autorstwa dra Michała Urbańczyka (UAM), zatytułowany "Motywy kryminalizowania mowy nienawiści”. Moderatorem tej oraz kolejnej części konferencji był prof. dr hab. Robert Zawłocki (UAM).

Następna część dotyczyła zagadnień związanych z codziennym funkcjonowaniem cudzoziemców i innych osób reprezentujących odmienne kultury w rozmaitych sferach życia społecznego. Referaty wygłosili: dr hab. Daniel Eryk Lach, prof. UAM ("Cudzoziemcy w polskim prawie socjalnym”), dr hab. Joanna Haberko, prof. UAM („Udzielanie świadczeń zdrowotnych cudzoziemcom”), prof. dr hab. Krzysztof Ślebzak, LL.M. (UAM) („Zabezpieczenie społeczne obywateli państw trzecich w Unii Europejskiej”), dr hab. Michał Skąpski, prof. UAM („Wielokulturowość jako wyzwanie w stosunkach pracy"), dr hab. Katarzyna Kokocińska, prof. UAM („Prawne aspekty działalności gospodarczej w kontekście wielokulturowości społeczeństw").

Przedostatni panel, którego moderatorem był prof. dr hab. Piotr Stępniak, poświęcony był przede wszystkim problematyce wielokulturowości w rozmaitych aspektach szeroko rozumianego życia gospodarczego oraz obrotu prawnego. Dr Filip Balcerzak, LL.M. (WSB) przedstawił refleksje dotyczące międzynarodowego prawa inwestycyjnego w kontekście wielokulturowości społeczeństwa. Następnie dr hab. Krzysztof Mularski (UAM) zaprezentował referat podejmujący wątek wykładni oświadczeń woli z uwzględnieniem aspektów wielokulturowości. Z kolei dr hab. Dominik Mączyński, prof. UAM omówił prawnopodatkowe aspekty wielokulturowości społeczeństwa, a dr hab. Anna Suchoń (UAM) - kwestie obrotu nieruchomościami rolnymi w kontekście wielokulturowości.

Konferencyjne rozważania zamknął panel, moderowany także przez prof. dra hab. Piotra Stępniaka, poświęcony sferze edukacji i kultury. Obejmował on wystąpienia osób reprezentujących UAM: dr hab. Katarzyny Klafkowskiej-Waśniowskiej („Ochrona różnorodności kulturowej w Unii Europejskiej w mediach audiowizualnych”) oraz dr Katarzyny Jadach („Wielokulturowość w systemie oświaty w Polsce”).

Zaznaczyć wypada, że wygłoszone referaty bądź ich poszerzone wersje zostaną wydane $w$ formie publikacji pokonferencyjnej. Bogactwo i waga poruszanych w nich wątków uzasadniają potrzebę kontynuowania debaty na podjęte podczas konferencji tematy - na co wskazywał m.in. prof. dr hab. dr h.c. Andrzej J. Szwarc, podsumowując i zamykając konferencję. W tym kontekście warto na koniec odnotować, że konferencja spotkała się ze znacznym zainteresowaniem studentów kierunków prawniczych Wyższej Szkoły Bankowej, którzy brali aktywny udział zarówno w jej przygotowaniu, jak i w dyskusjach podczas poszczególnych paneli. Ma to znaczenie o tyle, że - jak można sądzić - problem kulturowego zróżnicowania będzie odgrywał w pracy zawodowej kolejnych pokoleń prawników niebagatelną rolę.

Agnieszka Narożniak

DOI: $10.14746 /$ spp.2017.4.20.14 